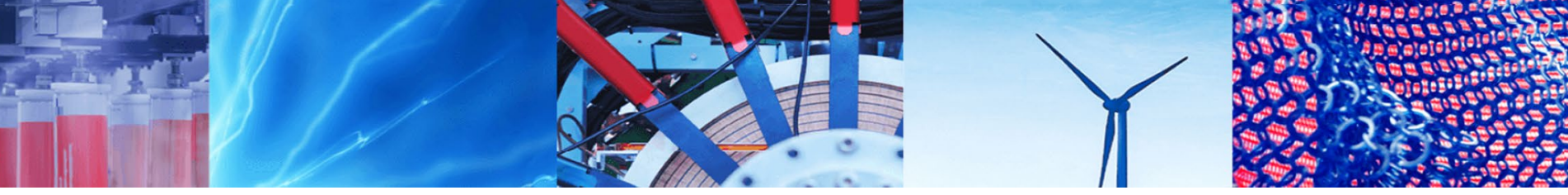

Research Article

\title{
A framework for welding process selection
}

\author{
Mohamed Omar ${ }^{1}\left[\right.$ ] Hassan Soltan ${ }^{1}$
}

Received: 31 August 2019 / Accepted: 31 January 2020 / Published online: 5 February 2020

(c) Springer Nature Switzerland AG 2020

\begin{abstract}
This paper develops a framework to differentiate welding processes, for industrial purposes, according to two families of criteria. It is constructed as a phase-wise decision support system that reviews objects with physical and economic criteria. The first phase excludes the non-functioning processes from the panel, and catching the best candidate processes are left to the second phase. The second phase is an integrated mechanism that weights the active criteria versus the goal using a FUZZY-AHP system and then it ranks the candidates using a FUZZY-TOPSIS system. Both phases operate linked with parallel and accessible database and knowledge-base to accommodate a large variety of welding factors (alternative welding processes and welding criteria) and allow inserting new ones. This framework is mechanized as a portable software, and then validated based on existing cases. The proposed framework is advantageous with having a flexible opened structure that can manage existing and expected industrial problems.
\end{abstract}

Keywords Welding process selection · MCDM · FUZZY AHP · FUZZY TOPSIS

\section{Introduction}

The manufacturing assemblies includes a large variety of welding methods. Furthermore, the design of a welding process involves several physical and economic factors even with using the same method. Thus, the selection of a welding method and its process design becomes a hard task. Conventionally, this task still depends mainly on the experience of manufacturing engineers linked with a few factors, mostly the discontinuity (an element of quality) and cost with a few number of welding processes. In the matter of fact, such routine becomes insufficient while the number of alternative processes increases for the same product as seen from Darwish et al. [10], and Jayant and Singh [17]. Therefore, it becomes essential to develop comprehensive systems to solve the welding process selection (WPS) problem with least time and effort. Any successful selection system should comprise an opened database collecting all information of welding methods/processes, products, and materials in addition to a dynamic knowledge-base. The latter contents enable defining, determining, and storing the exact welding problem factors.

It is obvious that the complexity of WPS problem increases as the problem factors increase, and in turn, the number of process differentiation criteria increases. Thus, the WPS represents an NP-hard problem that can't be solved with rough approaches. The WPS is a typical multicriteria decision making (MCDM) problem. Thus, MCDM methods such as TOPSIS (Technique for Order Preference by Similarity to Ideal Solution), AHP (Analytic Hierarchy Process) and their FUZZY versions become the most relevant to construct a successful system for the current purpose as seen later in this paper.

Several approaches were developed to solve the WPS problem. Most of these approaches are limited to small problems. These approaches can be categorized as Just advisory or guiding, simple methodological, and integrated methodological approaches.

Mohamed Omar, mohamed_omar@mans.edu.eg; Hassan Soltan, hasoltan@hotmail.com | ${ }^{1}$ Production Engineering and Mechanical Design Department, Faculty of Engineering, Mansoura University, Mansoura 35516, Egypt. 
However, this paper reviews the most relevant approaches and that related to the purpose. For instance, Darwish et al. [10] developed a knowledge-base system for solving the WPS problem and then experimented 30 welding processes. Their system includes the factors of product type, material type and thickness, method of use, quality level, joint type and welding position. Their system needs to a prescreening for the available welding processes. Also, they introduced a methodology to determine the most suitable joining technology based on highlighting the candidate processes that found capable of joining under given conditions. Their selection methodology comprises criteria like joint function (load type and strength), joint technical information (joint configuration and material type), joint spatial information (material thickness and size) and economic factors (production volume and required skills). The corresponding criteria are stored in a database and implemented in a software. Such systems merely candidate welding processes without robust selection mechanism. Yeo and Neo [32] explored quantitively the effect of welding methods on the environment and WPS using AHP with Crisp values.

Later, Silva et al. [27] demostrated a sequential mathematical approach for WPS based on quality and cost in Crisp values. They applied to SMAW, GTAW and two versions of GMAW processes. Balasubramanian et al. [3] reported a specific procedure for WPS using AHP with Crisp values in fabracting cruciform joints of ASTM 517 ' $F$ ' grade steel. They differentiated the SMAW, FCAW and SAW processes based on the qualitative criteria of initial preparation required, availability of consumables, welder skill requirement, welding procedures, quality of the weld, fatigue of the operator, post weld cleaning, ease of automation, and positional welding capability. Correia and Ferraresi [9] used their WPS method to compare SAW and GMAW processes based on operational costs and nonquality costs in Crisp values for a specific application.

More robust WPS systems were introduced such as that introduced by Esawi and Ashby [12] who described a methodology for joining method selection implemented in a software; where a search engine isolates the processes that meet design requirements of material, joint geometry and loading where the information about joining processes with respect to each criterion are stored in a database. The processes are isolated and then ranked based on the relative equipment cost or production rate; that is more relevant. Balasubramanian et al. [4] applied AHP in a
Crisp manner for WPS in fabricating hardface boiler grade steels. They differentiated SMAW, GMAW, GTAW, SAW and PTAW processes based on quantitative and qualitative factors. Their method reported PTAW as the best process for this application. Jafarian and Vahdat [16] described a WPS system consists of a knowledge-base and a FUZZY-AHPTOPSIS system and used this to differentiate nine important welding processes considering the criteria of operator factor, alloy class, material thickness, capital cost, deposition rate, design application, joint configuration, welding position, equipment portability, and filler metal utilization. Their system indicated that GTAW, PAW and EBW are the most suitable methods for welding the high pressure vessel. Mirhedayatian et al. [24] proposed a FUZZY-TOPSIS system for WPS in repairing nodular cast iron engine block. For this purpose, they compared SAW, PAW, TIG, GMAW, FCAW, SMAW, OFW, EBW and LBW processes.

More recent, Jayant and Singh [17] simply used a knowledge-base AHP system to decide a process for welding high pressure vessel. They differentiated five welding processes based on the criteria of design applications, joint configuration, welding position, capital cost, deposition rate, thickness of parts, weld quality, material class, welding procedure, operator factor filler, metal utilization, and equipment portability. Capraz et al. [8] used AHP and TOPSIS to select a process for welding plain carbon stainless steel storage tank. They used AHP to weight the criteria according to experts' opinion and used TOPSIS to rank available welding processes. They applied to MMAW, MIG, MAG, GTAW and SAW processes. However, the existing directions of solving the WPS problem vary according to the differentiation principle adopted.

The remaining of this paper is organized as follows. The proposed framework and its auxiliaries are described in Sect. 2 and demonstrated with case studies in Sect. 3. The sensitivity of the proposed framework is examined in Sect. 4. Concluding remarks are presented in Sect. 5. The paper also contains two appendices; Appendix 1 abbreviates the welding processes and Appendix 2 includes the procedural tables.

\section{The proposed framework}

The welding factors and sub-factors are found classified in several forms. This can be reviewed from Darwish et al. [10], Yeo and Neo [32], Silva et al. [27], Balasubramanian 
Fig. 1 The main welding factors

\section{WELDING FACTORS}

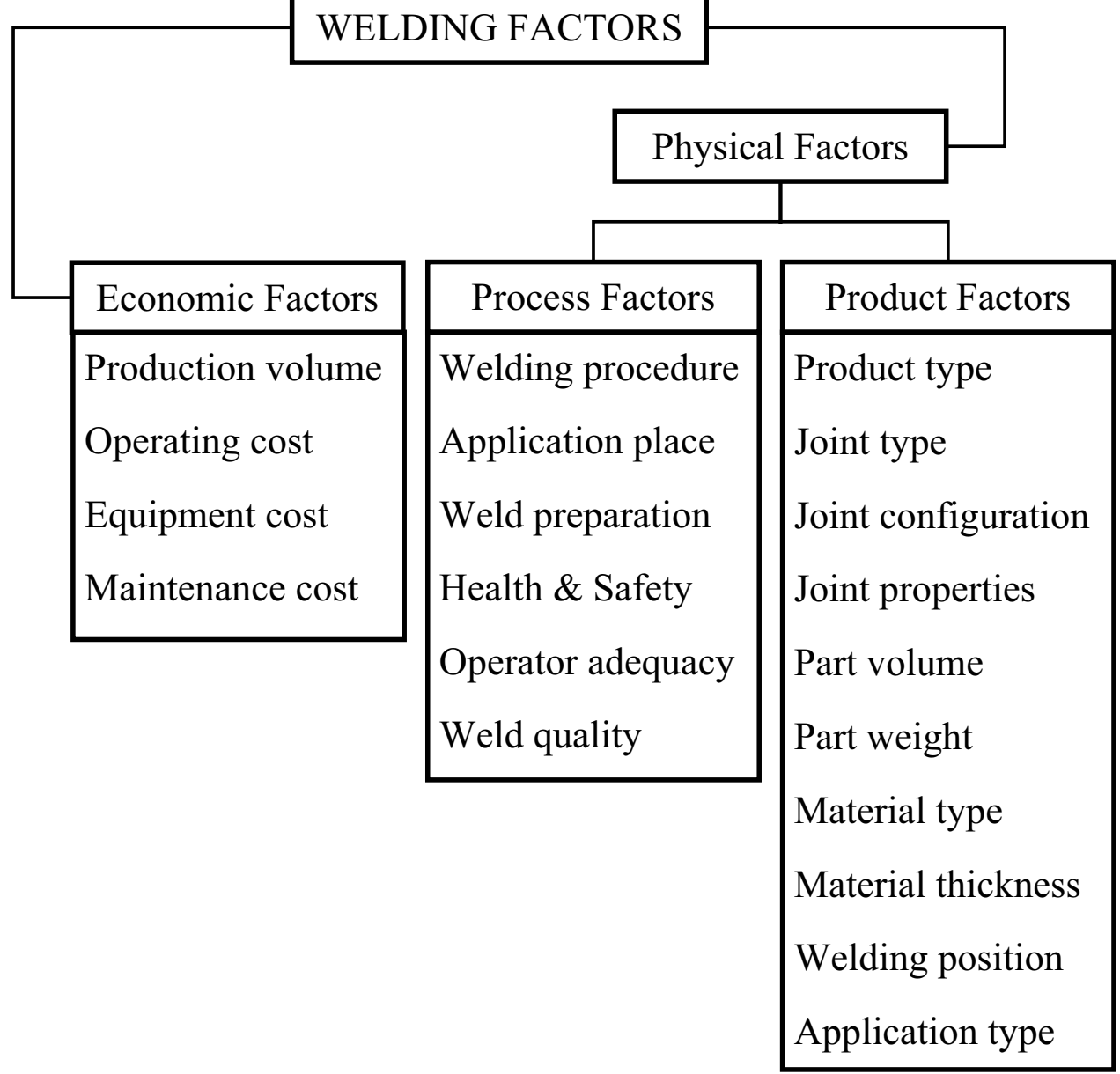

et al. [3], Brown et al. [7], Esawi and Ashby [12], Correia and Ferraresi [9], Balasubramanian et al. [4], Jafarian and Vahdat [16], and Mirhedayatian et al. [24]. However, this paper summarizes the main welding factors as shown in Fig. 1, which can be further classified.

Figure 2 explores the proposed framework for welding process selection. This framework is mainly an integrated MCDM system. The inception of this layout was introduced by Omar et al. [26]. The database and knowledge-base are constructed to include the welding factors and their related information of a group of 49 welding processes those abbreviated in Appendix 1. Based on the source/ cause of coalescence between the welded parts, this group is classified as follows.

- Pressure welding processes

- Fusion welding processes RSW, RSEW, RPW, HFW, FW, SW, CD-SW.

- Non-fusion welding processes UW, DFW, RLW, EXW, ICW, BCW, DCW, CEXW, FGW, FSW, FRW, USW.
- Non-pressure welding processes

- Homogenous welding processes SMAW, MIG, FCAW-G, FCAW-S, PE-TIG, TIG, SAW, P-MIG, L-MIG, PAW, EGW, ESW, EBW-V, EBW-NV, LBW, GW.

- Heterogeneous welding processes

$T B, D F B, D B, F B$, IB, RB, BZW, TS, DFS, DS, FS, IS, RS and THW.

To construct the database and knowledge-base, the relationships regarding the former welding processes with welding criteria are organized from four aiding sourcestextbooks, papers, and database of international welding companies and field visits for Egyptian international companies such as Suzuki Egypt and GS for Engineering \& Construction. Refer to Tables 4-14 in Appendix 2. Table 4 of welding companies is collected and arranged according to the factors and purpose. Tables 12 and 14 are also based on Table 4. Then, some relationships are set in a linguistic form, which will be transformed using the FUZZY logic. (Notice that Table 4 is concerned with some criteria and most of the welding processes.) Tables of Appendix 2 


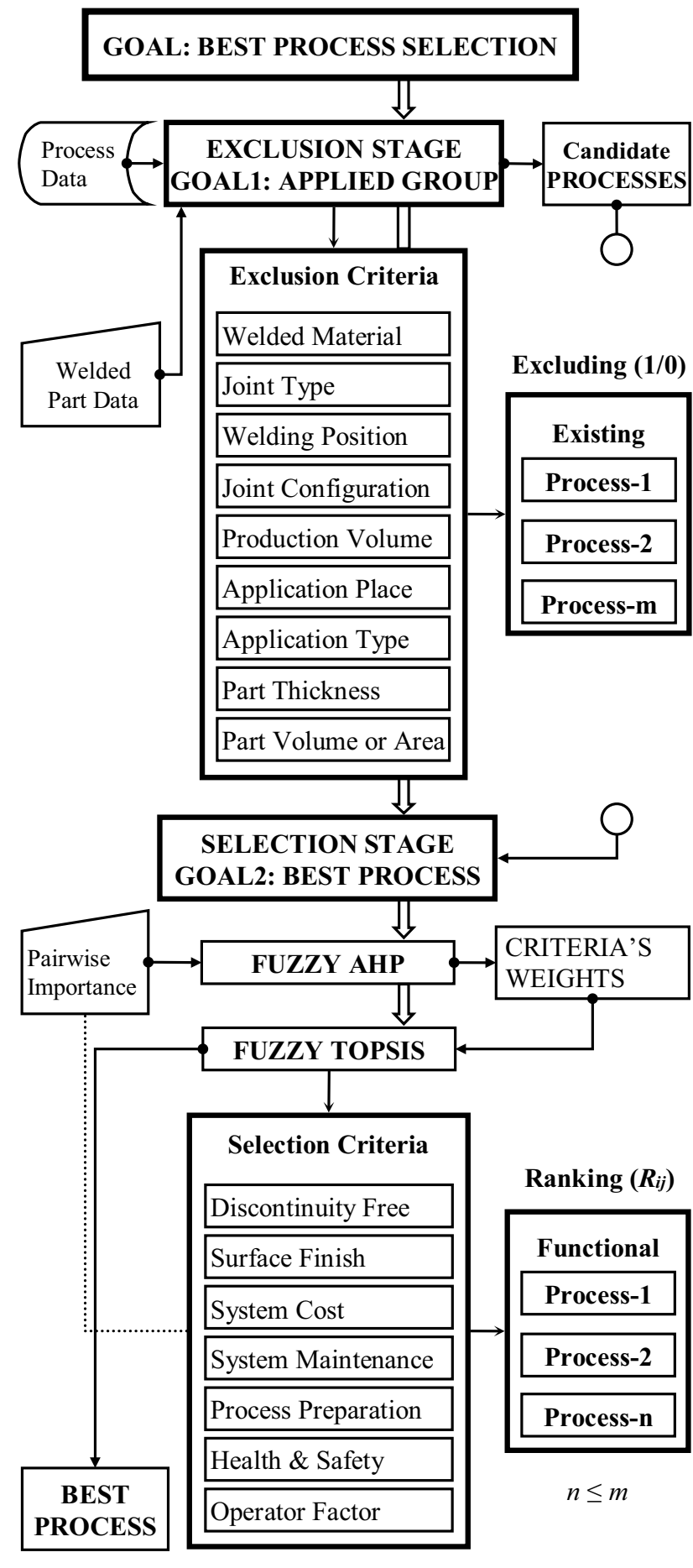

Fig. 2 Proposed framework for welding process selection

are associated with the used aiding sources with different degrees as shown in Table 1.

Making a decision about the best welding process for a given product is completed in two phases-exclusion phase and selection phase. Assisted by the engineers' opinions and other information, the AHP method is used to weight the welding criteria diffused with FUZZY logic (FUZZY-AHP) such as that followed in Huang et al. [15]. The TOPSIS method is used to find the final ranking of welding processes diffused with FUZZY logic (FUZZY-TOPSIS) such as that followed in Junior et al. [22].

The exclusion phase identifies the functional candidate group of welding processes amongst those submitted first and fathoms the other processes. Thus, the given welding processes are reduced to those meet working circumstances of nine factors - maximum and minimum welded part volume, material type, maximum and minimum joint thickness, production volume, weld position, joint type, applicable joint configuration, weld place, and possible applications.

The selection phase ranks the functional candidate group using FUZZY-TOPSIS method based on next seven factors-welding equipment cost, operator factor, maintenance complexity of welding equipment due to machine structure, surface finish, process preparation, health \& safety, and weld discontinuity free.

This framework is programmed in MATLAB environment and it can be introduced as software for users with the graphical user interface shown in Fig. 3. The user only feeds the information displayed. For each factor, the user selects from a pop-up-menu. The program is constructed to display the most preferable welding processes on the solution screen cell while other results are stored internally. The user supplies information about the relative importance (pairwise comparison matrix) of the seven selection criteria in criteria weights determination panel based on AHP Saaty's scale $\{1 / 9,1 / 8, \ldots, 1 / 2 ; 1,2, \ldots, 9\}$. Other information are also supplied following the instructions on the interface.

\section{Demonstration}

The framework is applied to three typical cases from industry (Figs. 4, 5, 6). The purpose is to find the best welding process for each application. The output becomes a list grades all welding processes as the best one on the top and so on. Table 15 in the Appendix 2 represents the pairwise comparison matrix of AHP for all cases.

To verify the results of the selection process, the FUZZY linguistic values of the seven selection criteria are judgmentally reviewed. From the other side, the current field practice validates the framework decisions. In addition, for the first two cases, the selected welding processes highly satisfy the physical and economic requirements of the weld. However, the selected welding process for the third case doesn't highly satisfy the required weld strength even this selection is the same as applied in the field practice. 
Table 1 Degree of involvement between the framework database and the aiding sources

\begin{tabular}{|c|c|c|c|c|c|c|c|c|c|c|c|}
\hline \multirow[t]{2}{*}{ Aiding source } & \multicolumn{11}{|c|}{ Tables in Appendix 2} \\
\hline & B1 & B2 & B3 & B4 & B5 & B6 & B7 & B8 & B9 & B10 & B11 \\
\hline Houldcroft [14] & & $* * *$ & $* * *$ & $* * *$ & $* * *$ & $* * *$ & $* * *$ & $* * *$ & & & \\
\hline Dawes [11] & & & & & & & & & & & * \\
\hline Alia et al. [2] & & $* *$ & * & * & $* * *$ & * & $* * *$ & $* *$ & & & \\
\hline Oates [25] & & $* * *$ & $* *$ & $* * *$ & $* * *$ & $* *$ & $* * *$ & $* * *$ & & & $* *$ \\
\hline Bralla [6] & & * & * & $* *$ & $* *$ & $* * *$ & $* * *$ & $* * *$ & & $* * *$ & \\
\hline Blunt and Balchin [5] & & & & & & & & & & & $* * *$ \\
\hline Harris [13] & & & & & & & & & & & $* *$ \\
\hline Ainali et al. [1] & & $* * *$ & & & & $* *$ & $*$ & $*$ & & & * \\
\hline Weman [31] & & & & & & & & & & & * \\
\hline Vianco et al. [29] & & $* * *$ & * & * & * & * & $* * *$ & $* *$ & & & $* *$ \\
\hline Jenny [21] & & $* * *$ & * & *** & $* * *$ & $* *$ & $* * *$ & *** & & & $* *$ \\
\hline Jenney and O'Brien [18-20] & & $* * *$ & $* * *$ & $* * *$ & $* * *$ & $* * *$ & $* * *$ & $* * *$ & & & $* *$ \\
\hline Webber et al. [30] & & & & & & & & & & & $* *$ \\
\hline Swift and Booker [28] & & *** & $* * *$ & *** & $* * *$ & $* * *$ & $* * *$ & *** & & $* * *$ & $* * *$ \\
\hline Jayant and Singh [17] & & & & & & & & & & $* *$ & \\
\hline International companies database & $* * *$ & & & & & & & & $* * *$ & & * \\
\hline Field visits for international Egyptian companies & & & & & & & & & & & *** \\
\hline $\begin{array}{l}\text { Minister of Innovaion and Advanced Education \& } \\
\text { Apprenticeship and Industry Training [23] }\end{array}$ & & & & & & & & & & & * \\
\hline
\end{tabular}

*Fair involvement; ${ }^{* *}$ strong involvement; ${ }^{* * *}$ very strong involvement

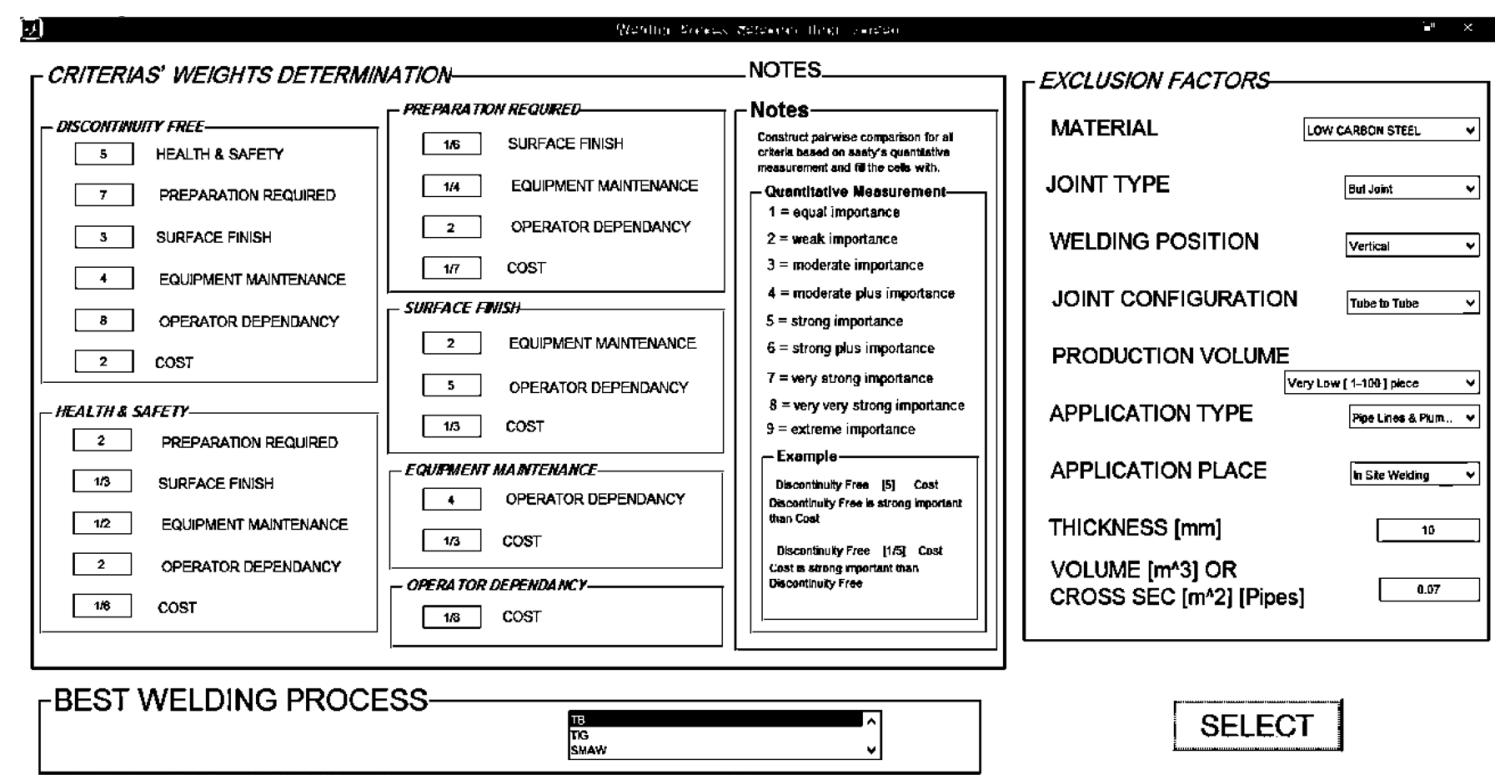

Fig. 3 The graphical user interface of the proposed framework 


\begin{tabular}{|l|l|}
\hline Outer diameter & $300 \mathrm{~mm}$ \\
\hline Occupied space & $0.07 \mathrm{~m}^{3}$ \\
\hline Thickness & $10 \mathrm{~mm}$ \\
\hline Material & Low carbon steel \\
\hline Type of joint & Butt \\
\hline Welding position & Horizontal \\
\hline Joint configuration & Tube to tube \\
\hline Production volume & 50 \\
\hline Type of application & Plumbing \\
\hline Place of application & In site \\
\hline Result top three processes: $T B \rightarrow T I G \rightarrow S M A W$. \\
\hline
\end{tabular}

Fig. 4 A plumbing butt joint welding

\begin{tabular}{|l|l|}
\hline Outer diameter & $300 \mathrm{~mm}$ \\
\hline Occupied space & $0.07 \mathrm{~m}^{3}$ \\
\hline Thickness & $10 \mathrm{~mm}$ \\
\hline Material & Mild steel \\
\hline Type of joint & Butt \\
\hline Welding position & Flat \\
\hline Joint configuration & Tube to tube \\
\hline Production volume & 1500 \\
\hline Type of application & Piping \\
\hline Place of application & Can be moved \\
\hline Result top three processes: $S A W \rightarrow P E-T I G \rightarrow F C A W-S$. \\
\hline
\end{tabular}

Fig. 5 A piping butt joint welding

\section{Sensitivity analysis}

It remains to examine the sensitivity of the proposed framework to potential changes in the inherent welding factors both qualitative and quantitative. In other words, for the same welding application, a selected welding process may be altered if one or more factors change. For this purpose, Table 2 explores fourteen cases extracted from plumping welding application type with application place 'in-site welding' and 'part volume of $0.07 \mathrm{~m}^{3}$ ', i.e., it is allowed to change six exclusion factors. Furthermore, it taken in consideration to impose extreme cases to further examine the robustness of the exclusion process as cases 4, 13 and 14.

Table 3 and Fig. 7 summarizes the sensitivity analysis of the proposed framework in terms of the fourteen cases

\begin{tabular}{|l|l|}
\hline Dimensions & $1000 \mathrm{~mm} \times 500 \mathrm{~mm}$ \\
\hline Occupied space & $0.001 \mathrm{~m}^{3}$ \\
\hline Thickness & $1 \mathrm{~mm}$ \\
\hline Material & Medium carbon steel \\
\hline Type of joint & Lap \\
\hline Welding position & Flat \\
\hline Joint configuration & Plate to plate \\
\hline Production volume & 1000 \\
\hline Type of application & Automotive \\
\hline Place of application & Can be moved \\
\hline Result top three processes: $T S \rightarrow B Z W \rightarrow T B$. \\
\hline
\end{tabular}

Fig. 6 An automotive lap joint welding

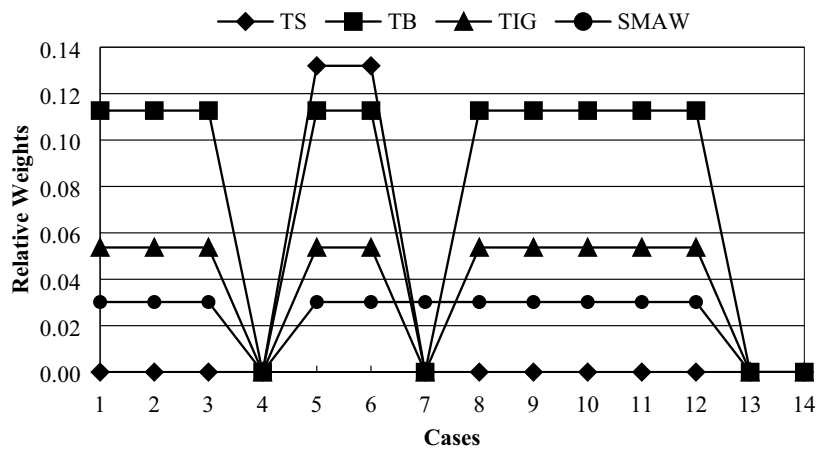

Fig. 7 Weights of candidate welding processes to the examined cases

addressed in Table 2 based on the relative weight (closeness). The candidate welding processes of this experiment are found TS, TB, TIG and SMAW, and cases 4, 13 and 14 are refused by all welding processes. Referring to the plumping application of Fig. 4, it is found that TB process is the best welding process and as it can be seen from Fig. 7 that TB still apply and dominate as a best process for the examined cases (57\% of cases) followed by TS (14\% of cases) and then SMAW (7\% of cases). Notice that the changes in the exclusion factors bring the TS process to the best panel and postpone the TIG process (Table 3). However, TB seems to be the most appropriate welding process for the 
Table 2 Different cases of the plumping application with fixed place and part volume

\begin{tabular}{|c|c|c|c|c|c|c|}
\hline \multirow[t]{2}{*}{ Case } & \multicolumn{6}{|l|}{ Exclusion Factor } \\
\hline & Welded material & Joint type & Welding position & Joint configuration & $\begin{array}{l}\text { Produc- } \\
\text { tion } \\
\text { volume }\end{array}$ & $\begin{array}{l}\text { Part thick- } \\
\text { ness (mm) }\end{array}$ \\
\hline 1 & Low carbon steel & Butt & Horizontal & Tube to tube & 50 & 10 \\
\hline 2 & Low carbon steel & Butt & Flat & Tube to tube & 50 & 10 \\
\hline 3 & Low carbon steel & Butt & Over head & Tube to tube & 50 & 10 \\
\hline 4 & Low carbon steel & Butt & Horizontal & Tube to tube & 1500 & 10 \\
\hline 5 & Low carbon steel & Butt & Horizontal & Tube to tube & 50 & 5 \\
\hline 6 & Low carbon steel & Butt & Horizontal & Tube to tube & 50 & 2 \\
\hline 7 & Low carbon steel & Butt & Horizontal & Tube to tube & 50 & 20 \\
\hline 8 & Mild steel & Butt & Horizontal & Tube to tube & 50 & 10 \\
\hline 9 & Medium carbon steel & Butt & Horizontal & Tube to tube & 50 & 10 \\
\hline 10 & Low carbon steel & T-joint & Horizontal & Tube to plate & 50 & 10 \\
\hline 11 & Mild steel & Butt & Horizontal & Tube to bar & 50 & 10 \\
\hline 12 & Mild steel & Butt & Horizontal & Tube to tube & 300 & 10 \\
\hline 13 & Mild steel & T-joint & Horizontal & Tube to plate & 1500 & 5 \\
\hline 14 & Mild steel & T-joint & Vertical & Tube to plate & 1500 & 5 \\
\hline
\end{tabular}

Table 3 Weights of candidate welding processes to the examined cases

\begin{tabular}{|c|c|c|c|c|c|c|c|c|c|c|c|c|c|c|c|}
\hline \multirow[t]{2}{*}{ Welding process } & \multicolumn{14}{|l|}{ Case } & \multirow[t]{2}{*}{$\%$ of cases } \\
\hline & 1 & 2 & 3 & 4 & 5 & 6 & 7 & 8 & 9 & 10 & 11 & 12 & 13 & 14 & \\
\hline TS & 0.00 & 0.00 & 0.00 & 0.00 & 0.13 & 0.13 & 0.00 & 0.00 & 0.00 & 0.00 & 0.00 & 0.00 & 0.00 & 0.00 & 14 \\
\hline $\mathrm{TB}$ & 0.11 & 0.11 & 0.11 & 0.00 & 0.11 & 0.11 & 0.00 & 0.11 & 0.11 & 0.11 & 0.11 & 0.11 & 0.00 & 0.00 & 57 \\
\hline TIG & 0.05 & 0.05 & 0.05 & 0.00 & 0.05 & 0.05 & 0.00 & 0.05 & 0.05 & 0.05 & 0.05 & 0.05 & 0.00 & 0.00 & 00 \\
\hline SMAW & 0.03 & 0.03 & 0.03 & 0.00 & 0.03 & 0.03 & 0.03 & 0.03 & 0.03 & 0.03 & 0.03 & 0.03 & 0.00 & 0.00 & 07 \\
\hline Best process & TB & TB & TB & None & TS & TS & SMAW & TB & TB & TB & TB & TB & None & None & 78 \\
\hline
\end{tabular}

The bold numbers were used to indicate the highest relative closeness value to identify the best welding process

plumping welding application type. Thus, the framework is sensitive to the significant changes in welding factors.

Intuitively, the welding application type is the most determinant of the best welding process followed by'part thickness' and then 'production volume'. The results proved that any significant changes in 'part thickness' can alter the selected process; for instance if all part thicknesses becomes $5 \mathrm{~mm}$, the TS process will replace the TB process in this experiment. This property enables the welding engineers to set a range of any quantitative factor in which a specific welding process still apply.

\section{Conclusions}

This paper introduces and applies a modular decision framework for welding process selection avoiding several shortcomings of exiting methods. It filters the submitted processes twice through a sequence of two sets of robust criteria including new ones such as health \& safety and system maintenance. This is actuated with an integrated powerful decision making engine. Thus, it can ensure the right decision of differentiating a wider range of industrial 
processes whatever the complexity of products and welding processes including recent situations. Furthermore, this framework can easily accommodate other criteria and evaluation functions since it becomes an inception for a portable software. This framework is verified and then validated with current industrial cases. The framework sensitivity to changes in the exclusion welding factors is also examined with hypothetical cases based on an industrial application. For a coming extension, the framework will be equipped with additional bundles of factors. A mechanical bundle will be merged to include factors such as weld strength to obtain more accurate and precise selection and to avoid such shortcoming of the third case.

\section{Compliance with ethical standards}

Conflict of interest On behalf of all authors, the corresponding author states that there is no conflict of interest.

\section{Appendix 1: Abbreviations of the considered welding processes}

\begin{tabular}{|c|c|c|c|}
\hline $\mathrm{BCW}$ & Butt cold welding & IB & Induction brazing \\
\hline BZW & Braze welding & ICW & $\begin{array}{l}\text { Indentation cold } \\
\text { welding }\end{array}$ \\
\hline CD-SW & $\begin{array}{l}\text { Capacitor discharge } \\
\text { stud welding }\end{array}$ & IS & Induction soldering \\
\hline CEXW & Co-extrusion welding & LBW & $\begin{array}{l}\text { Laser beam weld- } \\
\text { ing }\end{array}$ \\
\hline $\mathrm{DB}$ & Dip brazing & L-MIG & $\begin{array}{l}\text { Laser metal inert } \\
\text { gas }\end{array}$ \\
\hline DCW & Drawing cold welding & MAG & Metal active gas \\
\hline DFB & Diffusion brazing & MIG & Metal Inert gas \\
\hline DFS & Diffusion soldering & MMAW & $\begin{array}{l}\text { Manual metal arc } \\
\text { welding }\end{array}$ \\
\hline
\end{tabular}

\begin{tabular}{|c|c|c|c|}
\hline$\overline{\mathrm{DFW}}$ & Diffusion welding & OFW & $\begin{array}{l}\text { Oxy acetylene } \\
\text { welding }\end{array}$ \\
\hline DS & Dip soldering & PAW & Plasma arc welding \\
\hline EBW & Electron beam welding & PE-TIG & $\begin{array}{r}\text { Penetration } \\
\text { enhanced }\end{array}$ \\
\hline EBW-NV & $\begin{array}{l}\text { Electron beam weld- } \\
\text { ing-non vacuum }\end{array}$ & P-MIG & $\begin{array}{l}\text { Plasma metal inert } \\
\text { gas }\end{array}$ \\
\hline EBW-V & $\begin{array}{l}\text { Electron beam } \\
\text { welding-vacuum }\end{array}$ & PTAW & $\begin{array}{l}\text { Plasma transferred } \\
\text { arc welding }\end{array}$ \\
\hline EGW & Electro gas welding & $\mathrm{RB}$ & Resistance brazing \\
\hline ESW & Electro slag welding & RLW & Roll welding \\
\hline EXW & Explosive welding & RPW & $\begin{array}{l}\text { Resistance projec- } \\
\text { tion welding }\end{array}$ \\
\hline $\mathrm{FB}$ & Furnace brazing & RS & $\begin{array}{l}\text { Resistance solder- } \\
\text { ing }\end{array}$ \\
\hline FCAW & Flux cored arc welding & RSEW & $\begin{array}{l}\text { Resistance seam } \\
\text { welding }\end{array}$ \\
\hline FCAW-G & $\begin{array}{l}\text { Flux cored arc welding- } \\
\text { gas }\end{array}$ & RSW & $\begin{array}{l}\text { Resistance spot } \\
\text { welding }\end{array}$ \\
\hline FCAW-S & $\begin{array}{l}\text { Flux cored arc welding- } \\
\text { shielded }\end{array}$ & SAW & $\begin{array}{l}\text { Submerged arc } \\
\text { welding }\end{array}$ \\
\hline FGW & Forge welding & SMAW & $\begin{array}{l}\text { Shielded metal arc } \\
\text { welding }\end{array}$ \\
\hline FRW & Friction welding & SW & Stud welding \\
\hline FS & Furnace soldering & TB & Torch brazing \\
\hline FSW & Friction stir welding & THW & Thermite welding \\
\hline FW & Flash welding & TIG & Tungsten inert gas \\
\hline GMAW & Gas metal arc welding & TS & Torch soldering \\
\hline GTAW & $\begin{array}{l}\text { Gas tungsten arc } \\
\text { welding }\end{array}$ & USW & Ultrasonic welding \\
\hline GW & Gas welding & UW & Upset welding \\
\hline HFW & $\begin{array}{l}\text { High frequency weld- } \\
\text { ing }\end{array}$ & & \\
\hline
\end{tabular}

\section{Appendix 2}

See Tables 4, 5, 6, 7, 8, 9, 10, 11, 12, 13, 14 and 15 . 
Table 4 Some guiding International welding companies regrading some welding criteria and their weights

\begin{tabular}{|c|c|c|c|}
\hline No. & Company & Factor & Country \\
\hline 1 & Lincoln Electric & Equipment cost and maintenance & USA \\
\hline 2 & The Monty & Equipment cost and welded part volume & Canada \\
\hline 3 & Nelson Stud Welding & Equipment cost & USA \\
\hline 4 & SCIAKY Inc. & Equipment cost and maintenance & USA \\
\hline 5 & EPB Ltd. & Equipment cost & France \\
\hline 6 & USA Weld & Equipment cost & USA \\
\hline 7 & The Welders Warehouse & Equipment cost & UK \\
\hline 8 & Image Industries & Equipment maintenance & USA \\
\hline 9 & The Fabricator & Equipment maintenance & USA \\
\hline 10 & Modern Welding & Equipment maintenance & USA \\
\hline 11 & Government of South Australia & Equipment maintenance & Australia \\
\hline 12 & DBG & Equipment maintenance & UK \\
\hline 13 & OKUMA & Equipment maintenance & USA \\
\hline 14 & MTI Manufacturing Technology Inc. & Equipment maintenance & USA \\
\hline 15 & T.J. Snow & Welded part volume & USA \\
\hline 16 & Alumbra & Welded part volume & Sweden \\
\hline 17 & Culaser & Welded part volume & Turkey \\
\hline 18 & TWI & Welded part volume & UK \\
\hline 19 & RV Machine Tools & Welded part volume & India \\
\hline 20 & Pressure Welding Machines & Welded part volume & UK \\
\hline 21 & Nabertherm & Welded part volume & Germany \\
\hline 22 & $\mathrm{SOHO}$ & Welded part volume & China \\
\hline 23 & Wincoo Machine & Equipment cost & China \\
\hline 24 & NBXIN Chang & Equipment cost and welded part volume & China \\
\hline 25 & KIAIND & Equipment cost and welded part volume & China \\
\hline 26 & MORAN & Equipment cost & China \\
\hline 27 & FS Welder & Equipment cost and welded part volume & China \\
\hline 28 & Suzuki Egypt & All selection factors & Egypt \\
\hline 29 & GS for Engineering \& Construction & All selection factors & Egypt \\
\hline
\end{tabular}

Table 5 Materials that can be welded by sample processes

\begin{tabular}{lllll}
\hline Process & $\begin{array}{l}\text { Low carbon } \\
\text { steel }\end{array}$ & Mild steel & $\begin{array}{l}\text { Medium } \\
\text { carbon steel }\end{array}$ & $\begin{array}{l}\text { High } \\
\text { carbon } \\
\text { steel }\end{array}$ \\
\hline SMAW & Yes & Yes & Yes & Yes \\
MIG & Yes & Yes & Yes & Yes \\
FCAW-G & No & Yes & No & No \\
FCAW-S & No & Yes & No & No \\
PE-TIG & Yes & Yes & Yes & Yes \\
TIG & Yes & Yes & Yes & Yes \\
\hline
\end{tabular}

Table 6 Maximum and minimum part thickness for sample processes

\begin{tabular}{lll}
\hline Process & Minimum thickness $(\mathrm{mm})$ & $\begin{array}{l}\text { Maximum } \\
\text { thickness } \\
(\mathrm{mm})\end{array}$ \\
\hline SMAW & 1.6 & 38 \\
MIG & 0.5 & 80 \\
FCAW-G & 1.5 & 12 \\
FCAW-S & 1.5 & 12 \\
PE-TIG & 0.2 & 30 \\
TIG & 0.2 & 10 \\
\hline
\end{tabular}


Table 7 Applicability of sample processes to some joints

\begin{tabular}{llllll}
\hline Process & Butt joint & Corner joint & Tjoint & Lap joint & Edge joint \\
\hline SMAW & Yes & Yes & Yes & Yes & Yes \\
MIG & Yes & Yes & Yes & Yes & Yes \\
FCAW-G & Yes & Yes & Yes & Yes & Yes \\
FCAW-S & Yes & Yes & Yes & Yes & Yes \\
PE-TIG & Yes & Yes & Yes & Yes & Yes \\
TIG & Yes & Yes & Yes & Yes & Yes \\
\hline
\end{tabular}

Table 8 Applicability of sample processes to weld positions

\begin{tabular}{llllll}
\hline Process & Flat & $\begin{array}{l}\text { Horizon- } \\
\text { tal }(2 \mathrm{G})\end{array}$ & Horizontal $(2 \mathrm{~F})$ & Vertical & Overhead \\
\hline SMAW & Yes & No & Yes & Yes & Yes \\
MIG & Yes & No & No & No & No \\
FCAW-G & Yes & No & Yes & Yes & Yes \\
FCAW-S & Yes & No & No & Yes & Yes \\
PE-TIG & No & No & Yes & No & Yes \\
TIG & No & No & No & No & Yes \\
\hline
\end{tabular}

Table 9 Applicability of sample processes to part configurations

\begin{tabular}{lllllll}
\hline Process & $\begin{array}{l}\text { Plate to } \\
\text { plate }\end{array}$ & $\begin{array}{l}\text { Bar to } \\
\text { bar }\end{array}$ & $\begin{array}{l}\text { Bar to } \\
\text { tube }\end{array}$ & $\begin{array}{l}\text { Bar to } \\
\text { plate }\end{array}$ & $\begin{array}{l}\text { Tube to } \\
\text { tube }\end{array}$ & $\begin{array}{l}\text { Tube to } \\
\text { plate }\end{array}$ \\
\hline SMAW & Yes & Yes & Yes & Yes & Yes & Yes \\
MIG & Yes & No & Yes & Yes & Yes & Yes \\
FCAW-G & Yes & No & Yes & Yes & Yes & Yes \\
FCAW-S & Yes & No & Yes & Yes & Yes & Yes \\
PE-TIG & Yes & No & Yes & No & Yes & Yes \\
TIG & Yes & Yes & Yes & Yes & Yes & Yes \\
\hline
\end{tabular}

Table 10 Applications of some processes

\begin{tabular}{llllll}
\hline Process & Ship building & $\begin{array}{l}\text { Bridge } \\
\text { build- } \\
\text { ing }\end{array}$ & $\begin{array}{l}\text { Pressure } \\
\text { vessels }\end{array}$ & $\begin{array}{l}\text { Heavy } \\
\text { machin- } \\
\text { ery }\end{array}$ & $\begin{array}{l}\text { Pipelines/ } \\
\text { plumb- } \\
\text { ing }\end{array}$ \\
\hline SMAW & Yes & No & Yes & Yes & Yes \\
MIG & Yes & No & No & No & No \\
FCAW-G & Yes & No & Yes & Yes & Yes \\
FCAW-S & Yes & No & No & Yes & Yes \\
PE-TIG & No & No & Yes & No & Yes \\
TIG & No & No & No & No & Yes \\
\hline
\end{tabular}

Table 11 Applicability of sample processes to some places

\begin{tabular}{llll}
\hline Process & In site & Movable parts & $\begin{array}{l}\text { Continu- } \\
\text { ous weld- } \\
\text { ing }\end{array}$ \\
\hline SMAW & Yes & Yes & No \\
MIG & Yes & Yes & Yes \\
FCAW-G & Yes & Yes & Yes \\
FCAW-S & Yes & Yes & Yes \\
PE-TIG & Yes & Yes & Yes \\
TIG & Yes & Yes & Yes \\
\hline
\end{tabular}

Table 12 Maximum part volume/section area for sample processes

\begin{tabular}{ll}
\hline Process & Volume/area $\left(\mathrm{m}^{3}\right.$ or $\left.\mathrm{m}^{2}\right)$ \\
\hline RPW & $0.52272 \mathrm{~m}^{2}$ \\
HFW & $5.76 \mathrm{~m}^{3}$ \\
FW & $0.1 \mathrm{~m}^{2}$ \\
UW & $0.001024 \mathrm{~m}^{2}$ \\
DFW & $550.3992324 \mathrm{~m}^{3}$ \\
RLW & $8.55 \mathrm{~m}^{3}$ \\
EXW & $66 \mathrm{~m}^{3}$ \\
ICW & $0.00189 \mathrm{~m}^{2}$ \\
BCW & $0.0009 \mathrm{~m}^{2}$ \\
\hline
\end{tabular}

Table 13 Production volume for sample processes

\begin{tabular}{llllll}
\hline Process & Very low & Low & Medium & High & Very high \\
\hline SMAW & Yes & Yes & No & No & No \\
MIG & No & No & Yes & Yes & No \\
FCAW-G & No & No & Yes & Yes & No \\
FCAW-S & No & No & Yes & Yes & No \\
PE-TIG & No & No & Yes & No & No \\
TIG & Yes & Yes & No & No & No \\
\hline
\end{tabular}


Table 14 Sample processes weighted relative to the selection criteria

\begin{tabular}{|c|c|c|c|c|c|c|c|}
\hline Process & System cost & Operator factor & $\begin{array}{l}\text { System main- } \\
\text { tenance }\end{array}$ & Surface finish & Preparation & Health and safety & $\begin{array}{l}\text { Discon- } \\
\text { tinuity } \\
\text { Free }\end{array}$ \\
\hline SMAW & V. low & V. high & V. low & Med. & Med. & V. high & V. low \\
\hline MIG & Low & High & High & High & High & V. high & Low \\
\hline FCAW-G & Low & High & High & High & High & High & Low \\
\hline FCAW-S & Low & High & Med. & High & Med. & High & Low \\
\hline PE-TIG & V. low & Low & Med. & V. high & High & V. high & Low \\
\hline TIG & V. low & V. high & Med. & V. high & High & V. high & Low \\
\hline
\end{tabular}

Table 15 Pairwise comparison matrix of selection criteria for the cases

\begin{tabular}{llllllll}
\hline Criteria & System cost & $\begin{array}{l}\text { Opera- } \\
\text { tor } \\
\text { factor }\end{array}$ & $\begin{array}{l}\text { System } \\
\text { mainte- } \\
\text { nance }\end{array}$ & Surface finish & $\begin{array}{l}\text { Preparation } \\
\text { Health }\end{array}$ & $\begin{array}{l}\text { Discon- } \\
\text { and } \\
\text { safety }\end{array}$ & $\begin{array}{l}\text { free } \\
\text { free }\end{array}$ \\
\hline System cost & 1 & 8 & 3 & 3 & 7 & 8 & $1 / 2$ \\
Operator factor & $1 / 8$ & 1 & $1 / 4$ & $1 / 5$ & $1 / 2$ & $1 / 2$ & $1 / 8$ \\
Maintenance & $1 / 3$ & 4 & 1 & $1 / 2$ & 4 & 2 & $1 / 4$ \\
Surface finish & $1 / 3$ & 5 & 2 & 1 & 6 & 3 & $1 / 3$ \\
Preparation & $1 / 7$ & 2 & $1 / 4$ & $1 / 6$ & 1 & $1 / 2$ & $1 / 7$ \\
Health and safety & $1 / 8$ & 2 & $1 / 2$ & $1 / 3$ & 2 & 1 & $1 / 5$ \\
Discontinuity free & 2 & 8 & 4 & 3 & 7 & 5 & 1 \\
\hline
\end{tabular}

\section{References}

1. Ainali M, Falkenö A, Robinson R (eds) (2006) Luvata, CuproBraze Brazing Handbook, 8th edn. Västerås, Sweden

2. Alia BL, Alley RL, Leroy D, Siewert TA, Liu S, Edwards GR (1993) Welding brazing and soldering, vol 6. American Society for Metals, Cleveland

3. Balasubramanian BGV, Swamidas ASJ, Seshadri R (2000) Selection of welding process to fabricate cruciform joints using analytic hierarchic process based on qualitative factors. Sci Technol Weld Join 5:203-207

4. Balasubramanian V, Varahamoorthy R, Ramachandran CS, Muralidharan C (2009) Selection of welding process for hardfacing on carbon steels based on quantitative and qualitative factors. Int J Adv Manuf Technol 40:887-897

5. Blunt J, Balchin NC (2002) Health and safety in welding and allied processes. CRC Press, Boca Raton

6. Bralla J (1998) Design for manufacturability handbook. McGrawHill Professional, New York

7. Brown NJ, Swift KG, Booker JD (2002) Joining process selection in support of a proactive design for assembly. Proc Inst Mech Eng J Eng Manuf 216(10):1311-1324

8. Capraz O, Meran C, Warner W, Gungor A (2015) Using AHP and TOPSIS to evaluate welding processes for manufacturing plain carbon stainless steel storage tank. Arch Mater Sci Eng 76(2):157-162

9. Correia DS, Ferraresi VA (2007) Welding process selection through a double criteria: operational costs and non-quality costs. J Mater Process Technol 184:47-55

10. Darwish SM, Tamimi AA, Al-Habdan S (1997) A knowledge base for metal welding process selection. Int J Mach Tools Manuf 37(7):1007-1023
11. Dawes CT (1992) Laser welding: a practical guide. Abington Publishing, Cambridge

12. Esawi AMK, Ashby MF (2004) Computer-based selection of joining processes methods, software and case studies. Mater Des 25(7):555-564

13. Harris M (2002) Welding health and safety: a field guide for OEHS professionals. AlHA Press, Virginia

14. Houldcroft P (1990) Which process?. Abington Publishing, Cambridge

15. Huang J, Zhang T, Wang X, Liao Z (2013) TOPSIS based on the triangular fuzzy function and its application in construction scheme optimization. In: The 10th international conference on fuzzy systems and knowledge discovery (FSKD), pp 332-337

16. Jafarian M, Vahdat SE (2012) A fuzzy multi-attribute approach to select the welding process at high pressure vessel manufacturing. J Manuf Process 14(3):250-256

17. Jayant A, Singh M (2015) Use of analytic hierarchy process (AHP) to select welding process in high pressure vessels manufacturing environement. Int J Appl Eng Res 10(8):5869-5884

18. Jenney CL, O'Brien A (2011) Materials and applications, part I, vol 1. American Welding Society, Miami

19. Jenney CL, O'Brien A (2011) Welding processes, part I, vol 1. American Welding Society, Miami

20. Jenney $C L$, O'Brien $A$ (2011) Welding processes, part II, vol 1 (2011)

21. Jenney AOC (2011) Welding science and technology. American Welding Society, Miami

22. Junior FRL, Osiro L, Carpinetti LCR (2014) A comparison between fuzzy AHP and fuzzy TOPSIS methods to supplier selection. Appl Soft Comput 21:194-209

23. Minister of Innovaion and Advanced Education \& Apprenticeship and Industry Training: Submerged Arc Welding, Welder, Alberta Queen, Canada (2014) 
24. Mirhedayatian SM, Vahdat SE, Jelodar MJ, Saen RF (2013) Welding process selection for repairing nodular cast iron engine block by integrated fuzzy data envelopment analysis and TOPSIS approaches. Mater Des 43:272-282

25. Oates WR (ed) (1996) Materials and applications, part I, vol 3, 8th edn. American Welding Society, Miami

26. Omar MA, Elerian FA, Soltan HA, Ghattas MS (2018) An integrated approach for welding process selection. Mansoura Eng $J$ (MEJ) 43(1)

27. Silva CR, Ferraresi VA, Scotti A (2000) A quality and cost approach for welding process selection. J Braz Soc Mech Sci 22:389-398

28. Swift KG, Booker JD (2013) Manufacturing process selection handbook. Butterworth-Heinemann, Oxford
29. Vianco PT et al (2011) (AWS C3, Committe on Brazing and Soldring), Brazing handbook, 5th edn. American Welding Society, Miami

30. Webber T, Lieb T, Mazumder J (2011) Welding fundamentals and processes, vol 6A. American Society for Metals, Cleveland

31. Weman K (2006) MIG welding guide. Woodhead Publishing, Sawston

32. Yeo SH, Neo KG (1998) Inclusion of environmental performance for decision making of welding processes. J Mater Process Technol 82:78-88

Publisher's Note Springer Nature remains neutral with regard to jurisdictional claims in published maps and institutional affiliations. 